\title{
A case of 3 months old Japanese boy with sporadic congenital none-autoimmune hyperthyroidism
}

\author{
Saori Kinjo ${ }^{1 *}$, Masayuki Kanno ${ }^{2}$, Kei Matayoshi ${ }^{1}$, Kiyotaka Takefuta ${ }^{1}$, Ayako Izumi ${ }^{1}$, Chiho Sugisawa ${ }^{3}$, \\ Satoshi Narumi ${ }^{4}$, Moriyasu Kohama \\ From 8th APPES Biennial Scientific Meeting \\ Darwin, Australia. 29 October - 1 November 2014
}

Sporadic congenital none-autoimmune hyperthyroidism is rare disease. It causes the gain of function with TSH receptor gene mutation. We report 3 months old Japanese boy with sporadic congenital none-autoimmune hyperthyroidism. Our case was born in the 34th week of gestation with a birth weight $1830 \mathrm{~g}$, his length $42.0 \mathrm{~cm}$, his head circumference $29.5 \mathrm{~cm}$ as low birth weight baby between non consanguineous parents. Oligohydramnios was pointed out his perinatal period. There was no history of thyroid disease in other family members. He showed failure to thrive after the age of one month in spite of increasing nutrition. At the age of 3 months, His weight was $3.5 \mathrm{~kg}$, his length $54.6 \mathrm{~cm}$. He presented with tachycardia $(170 \sim 180 / \mathrm{min})$, severe sweating, mild exophthalmos and no goiter. We examined carefully and found he was suffered from hyperthyroidism. The thyroid function showed TSH $<0.005 \mu \mathrm{IU} / \mathrm{ml}$, fT3 $20.55 \mathrm{pg} / \mathrm{ml}$, fT4 $7.43 \mathrm{ng} / \mathrm{dl}$, Tg603 ng/ml with tests for anti-thyroid antibodies negative. His thyroid ultrasonography showed enlarged as his age, $99 \mathrm{mTcO} 4$ - scintiscan of thyroid gland showed a homogeneous uptake. His bone age was advanced to 2 years old. Brain MRI showed normal image for his age. His mother had no goiter and had not showed symptoms of hyperthyroidism. Tests for antithyroid antibodies were negative with her. We detected TSH receptor gene mutation with our case. The mutation is heterozygous and shows c842G $>$ A,p.Ser281Asn that had been reported before. The boy was treated with amount of $0.8 \mathrm{mg} / \mathrm{kg} /$ day of methimazole, his irritability disappears and his heart rate is down. Now his weight gains slowly and his development is appropriate for his age. We

'Department of Pediatrics, Okinawa Chubu Hospital, Miyazato, Uruma,

Okinawa Prefecture, Japan

Full list of author information is available at the end of the article conclude that careful examination and follow up need for his development and growth because the severity of sporadic congenital none-autoimmune hyperthyroidism is variety and most reported case were recurrent.

Written informed consent was obtained from the patient's parent or guardian for publication of this abstract and any accompanying images. A copy of the written consent is available for review by the Editor of this journal.

\section{Authors' details}

'Department of Pediatrics, Okinawa Chubu Hospital, Miyazato, Uruma, Okinawa Prefecture, Japan. ${ }^{2}$ Department of Naonatology, Okinawa Chubu Hospital, Japan. ${ }^{3}$ Department of Endocrine \& Metabolism, Showa University Fujigaoka Hospital, Japan. ${ }^{4}$ Department of Pediatrics, Keio University, Japan.

Published: 28 April 2015

doi:10.1186/1687-9856-2015-S1-P98

Cite this article as: Kinjo et al:: A case of 3 months old Japanese boy with sporadic congenital none-autoimmune hyperthyroidism. International Journal of Pediatric Endocrinology 2015 2015(Suppl 1):P98.

Submit your next manuscript to BioMed Central and take full advantage of:

- Convenient online submission

- Thorough peer review

- No space constraints or color figure charges

- Immediate publication on acceptance

- Inclusion in PubMed, CAS, Scopus and Google Scholar

- Research which is freely available for redistribution 